of Michigan), and "Links on the Chain: Songs of the Labor and Civil Rights Movement" demonstrated how drama and music can be effective history and teaching devices as well as entertainment. Collette A. Hyman (University of Minnesota) observed the ways in which dramatic presentations of two quite different unions reflected their labor philosophies. The efforts of the International Ladies' Garment Workers' Union (ILGWU) were professional and conventional while the productions of the Wholesale and Warehouse Workers were rank-and-file attempts to challenge existing institutions. Nora Faires (University of Michigan, Flint) described how a class project on the 1937 sit-down strike brought students and participants together to make a vivid experience out of that fifty-year-old event. In the evening, Michael Honey (Wesleyan University) and David Sawyer accomplished the same thing in an occasional sing-along concert.

Contrary to past experience, the last day brought higher attendance than had the previous two. Daniel Leab presided over a popular session on "Unions and the Rejection of Radicalism" in which Gary L. Bailey (Indiana University), Robert G. Picard (Louisiana State University), and Ronald Edsforth (Skidmore College) concentrated on the 1940s and 1950s in studies of the late career of Powers Hapgood (Bailey); the New York Newspaper Guild (Picard); and the UAW (Edsforth). They agreed that organized labor participated fully in the growing anticommunism of the time, fanned as it was by United States-Soviet rivalry. They stressed the role of unions as barometers and purveyors of public opinion.

Finally, at a luncheon gathering directed by Sidney Fine (University of Michigan), Daniel Nelson (University of Akron) made a case for the limited extent to which scientific management practices affected working conditions during the movement's "twilight" years, 1915-25.

By almost any measure, the three-day meeting was a success: more people came than ever before; a record number of sessions was held; and the spirited debates at those sessions often continued beyond the confines of the meeting rooms. Excluding the national professional conventions, the North American Labor History Conference is now the most important annual conference among American labor historians.

\title{
The American Historical Association, Part 1
}

\author{
Paul Mishler \\ Vassar College
}

Among the topics addressed at the December 1987 annual meeting of the American Historical Association were such seemingly far afield areas as white working-class resistance to school desegregation in the United States during the 1960s, the migration of Finnish-American Communists to Soviet Karelia during the 1930s, and the 
attitudes of the German Social Democratic party toward homosexuality during the first two decades of the century. Yet each of these sessions raised questions about the relationship between left-wing political analysis and social struggles in which the lines were drawn around cultural attitudes not directly connected to class struggles.

At a session on "Reactionary Populism," Ronald P. Formisano (Clark University) discussed "Reactionary Populism: The Anti-Busing Movement in Boston" and Jonathan Reider (Yale University) presented a paper entitled " Jews Run, Italians Stand Fast': White Backlash in Canarsie, Brooklyn, 1960-1980." Formisano's paper dealt with responses to court-ordered desegregation during the early 1970s in South Boston. He focused on the anger of the antibusing movement toward what its members perceived as their victimization by well-off suburban liberals whose own children were not affected. He analyzed the structures of economic and political power in Boston, which excluded white working-class communities from any effective control over their communities, and the differences in the styles of antibusing activity between South Boston and wealthier West Roxbury. He appealed to his audience to understand and appreciate the class resentment behind reactionary populism and to refrain from hastily using labels such as "bigot" and "racist" without understanding the feelings of those they would label.

Reider's paper dealt with Jewish and Italian working-class responses in Brooklyn during a similar school-desegregation process. He focused on the local breakup of the New Deal coalition in the Democratic party in New York because of the perception that the party at both the city and national levels was no longer listening to white working-class citizens. Most interestingly while both Jewish and Italian residents of Canarsie opposed desegregation, the Jews were ambivalent about the antidesegregation movement because they recognized its strong right-wing or "fascist" character.

There were two interconnected problems with both papers. First, both assumed that the class dimensions of these movements were ignored by prodesegregation forces during the $1960 \mathrm{~s}$ and $1970 \mathrm{~s}$ in favor of a "holier-than-thou" condescension. Particularly in Boston, this was not the case. As a member of the audience noted, the antibusing movement in Boston consciously emphasized class issues in order to diffuse the charge of racism: class issues also figured in discussions among antiracist activists. Second, there was no discussion of the role of black movements in demanding desegregation in either paper. Thus the rise of reactionary populism was seen as a result of struggles between wealthy and working-class whites only, which was patently not the case.

A session on "Immigrant Ambivalence" included three papers by Finnish scholars from Turku University: Auvo Kostiainen, Reino Kero, and Keijo Virtanen. George Pozzeta (University of Florida) commented, and the session was chaired by Melvin G. Holli (University of Illinois).

Each paper dealt with the relationship between radicalism and ethnic identity. Kostiainen described the often conflictual relationship among the leadership of the U.S. Communist party, the Communist International, and the Finnish-American Communists. The Communist party leadership was concerned that Finnish-American 
Communists were more interested in the cultural life they had developed in their Finn Halls and cooperatives than in joining with non-Finns in the political struggle. In 1930 the International sent a representative to take charge of work among the Finns. In the wake of this debate, Finnish participation in the Communist movement dropped.

Reino Karo and Keijo Virtanen discussed the issue of Finnish repatriation. Karo noted that about 20 percent of all Finns living in the U.S. returned to Europe, with about six thousand going to Soviet Karelia between 1920 and 1932. Karo noted that Finns who emigrated to Karelia from the U.S. tended to be older and more likely to be traveling with families than were immigrants to the United States thirty years earlier. Furthermore more Finns going to Karelia in the high years of "Karelia Fever," 193132, were members of the Communist party than were Finns generally. Finally, because they were readers of left-wing newspapers they were fearful of potential unemployment, even though they were less likely to be actually unemployed.

Keijo Virtanen noted that about 90 percent of all Finns had wanted to return to Finland, but that only 20 percent were ever to make the return trip. He suggested that this might account for the resistance to assimilation among Finnish-Americans of all political persuasions. Virtanen concluded that Finnish-Americans were responsible for the spread of socialist ideas in the rural areas of Finland, because many immigrants returned to the villages from which they or their families had come.

Two points raised by these papers seem most important. First, the attachment of the Finns to their own ethnic culture and their rejection of assimilation, whether demanded by the Communist party leadership or by more conservative Americanizers, seems to have been based in the desire of Finns to return home. At the same time, both left-wing and conservative Finns seemed unable to bridge the gap between the Finnish culture of the immigrant generation and the Finnish-American culture of their American-born children. Politically this meant that socialism remained tied to the Finnish-language culture of the immigrants, and never spread in any significant way to the immigrants' children as, for example, occurred among the Englishspeaking children of immigrant Jewish radicals.

The third panel I attended dealt with attitudes toward male homosexuality on the part of the German left from the end of the nineteenth century to the Nazi takeover. Two papers were presented: James Steakley (University of Wisconsin) talked on "Sexual Politics, Homosexuality, and the German Left, 1895-1935"; and Harry Oosterhuis (University of Amsterdam) presented a paper entitled "Klaus Mann, the Left, and Homosexuality." Both papers considered the paradox that both the Social Democratic and the Communist parties of Germany officially supported the removal of legal restrictions on homosexual relations while at the same time they maintained a marked homophobic antagonism.

Steakley's paper dealt primarily with the Social Democratic party. He pointed out that Social Democrats saw homosexuality as an aristocratic vice expressing the decadence of capitalist society. Oosterhuis's paper was based on a pamphlet by Klaus Mann criticizing the homophobia of the antifascist movement during the 1930s. Oosterhuis talked about how the Left considered homosexuality intricately connected 
with Naziism, in part because of the openly acknowledged homosexuality of Ernst Roehm, head of the Nazi Sturmabteilung (SA), and in part because the left saw the masculinist ideology of the right as homoerotic.

The contention of both papers that homosexuals were wrong to see the left as their friends when left-wing parties were the only ones consistently to support the removal of legal restrictions on homosexual behavior seems politically shortsighted and anachronistic.

All three sessions raised questions concerning the relationship between the values and ideologies of the left and the existence of cultural contradictions that defy the historical leftist analysis of the centrality of class. Particularly in advanced capitalist countries, these cultural contradictions have required and still require more subtle analysis on the part of the left, particularly with regard to struggles over ethnic and gender issues.

\title{
The American Historical Association, Part 2
}

\author{
Elizabeth Blackmar \\ Columbia University
}

At the panel on "Changing Forms: New York City Neighborhoods in the Depression," three historians from New York University examined strategies of formal and informal working-class organizing during the 1930s and raised important questions about class and community relations beyond the paid workplace.

In "Thunder out of Chinatown: The Activities of the New York Chinese Hand Laundry Alliance (CHLA) in the 1930s," Renqiu Yu showed how self-employed laundry workers broke with the authority of traditional district/family organizations (particularly the powerful Chinese Consolidated Benevolent Association) in order to pursue a progressive agenda that ranged from reducing burdensome and discriminatory license fees to recruiting American support for China following the Japanese invasion. In "Cafes, Clubs, Corners, and Candy Stores: Youth Leisure Culture on the Lower East Side during the 1930s," Suzanne Wasserman examined how Jewish and Italian youth used what social workers labeled the "enforced leisure" of unemployment to assert new forms of cultural autonomy. In addition to documenting the attractions of commercial leisure institutions such as movies and cafes, she uncovered the vital social life of "cellar clubs," where working-class youth invested their limited funds in creating their own recreational space. Annelise Orleck's paper, "We Were A Unified Working Class Community - Women's Neighborhood Organizing in the 1920 s and 1930s," showed how "class conscious mothers and consumers," many of whom had grown up in the context of garment workers' struggles, organized the United Council of Working Class Women (later the Progressive Women's Council) and 